\title{
Kemahiran Meta Kognitif Kanak-Kanak dalam Penggunaan Perisian dan Peranti Input Tanpa Sentuhan Leap Motion
}

\author{
Children's Metacognitive Skills in the Usage of Leap Motion Software \\ and Touchless Input Device
}

\author{
Suhairun Nizam Supal ${ }^{1}$, Maizatul Hayati Mohamad Yatim²* \\ ${ }^{1}$ Universiti Pendidikan Sultan Idris; ronvpower@gmail.com \\ ${ }^{2}$ Universiti Pendidikan Sultan Idris; maizatul@fskik.upsi.edu.my
}

* Corresponding author

To cite this article (APA): Supal, S. N., \& Yatim, M. H. M. (2020). Kemahiran meta kognitif kanak-kanak dalam penggunaan perisian dan peranti input tanpa sentuhan Leap Motion. Journal of ICT in Education, 7(2), 1-13. https://doi.org/10.37134/jictie.vol7.2.1.2020

To link to this article: https://doi.org/10.37134/jictie.vol7.2.1.2020

\begin{abstract}
Abstrak
Kemahiran metakognitif memainkan peranan penting bagi kanak-kanak untuk belajar bagaimana mengurus, mengawal dan memikirkan cara belajar. Artikel ini menerangkan kajian mengenai penggunaan peranti input tanpa sentuhan dalam mengembangkan kemahiran metakognitif kanakkanak dalam persekitaran pembelajaran. Kajian ini menggunakan kajian kes deskriptif dengan seorang kanak-kanak berusia empat tahun menggunakan peranti tanpa sentuhan Leap Motion Controller dengan tiga jenis perisian aplikasi. Kajian ini mengikuti Model Meta Kognitif Pemantauan oleh Flavell yang merangkumi empat kelas fenomena dan hubungannya. Artikel ini menerangkan penemuan dari sesi temu ramah dengan tiga orang guru, rakaman video dan sesi pemerhatian berstruktur. Penemuan menunjukkan bahawa bukan sahaja tahap kemahiran metakognitif untuk kanak-kanak yang terpilih ini meningkat, ia juga menunjukkan peningkatan kemahiran motor halus. Penggunaan peranti input tanpa sentuhan mempunyai kaitan dengan pengalaman kanak-kanak, kesesuaian interaksi dan antara muka aplikasi, dan kemampuan kanak-kanak dalam berlatih dan mengaplikasikan isyarat dan gerakan jari dan tangan. Kesimpulannya, kanak-kanak ini bersedia menggunakan peranti input tanpa sentuhan untuk pembelajaran abad ke-21. Implikasinya, peranti input tanpa sentuhan boleh digunakan dalam aktiviti pembelajaran untuk mengembangkan kemahiran metakognitif dalam kalangan kanak-kanak generasi muda.
\end{abstract}

Kata Kunci: peranti input tanpa sentuhan, kemahiran meta kognitif, Leap Motion, kanak-kanak.

\section{Abstract}

Metacognitive skills play important roles for children to learn on how to manage, to control and to think on how to learn. This article explains a study on the usage of a touchless input device in developing a child's metacognitive skills in a learning environment. The study used a descriptive case study with one child aged four years old using a Leap Motion Controller touchless device with three 
different types of application software. It follows the Flavell's Model of Metacognitive Monitoring which included four classes of phenomena and their relationships. This article describes findings from the interview sessions with the three teachers, video records and structured observation sessions. The findings show that not only the level of metacognitive skill for the selected child is increased, it also shows the increased of the fine motor skills. The usage of the touchless input device relates with the child's experiences, the suitability of interaction and applications' interface, and the child's ability in practicing and applying gestures and movements of the fingers and hands. In conclusion, the child is ready to use the touchless input device for the 21 st century learning. It also implies that touchless input devices can be infused in learning activities to develop metacognitive skills among children for a younger generation.

Keywords: touchless input device, metacognitive skills, Leap Motion, children.

\section{PENGENALAN}

Kebiasaannya kanak-kanak akan melalui sesi pembelajaran dengan menilai pengetahuan sedia ada tanpa disedari (Nahar, Sangi, Rosli, \& Abdullah, 2018). Proses ini melibatkan kemahiran meta kognitif yang dikatakan memainkan peranan penting dalam proses pembelajaran baharu. Kanak-kanak yang mempunyai kemahiran meta kognitif yang baik dikatakan berjaya mengurus dan mengawal proses pembelajaran mereka (Nurul \& Ramlah, 2020). Namun, perkembangan dunia teknologi maklumat dan persekitaran kanak-kanak telah membahagikan mereka kepada kelompok yang dikenali sebagai generasi (Rusman, Ismail \& Jaafar, 2019; McCrindle, 2018). Pada tahun 2020, generasi kanak-kanak merupakan mereka yang lahir pada tahun 1996-2010 yang dikenali sebagai Generasi Z (Gen Z).

Perkembangan dunia teknologi maklumat dan persekitaran kanak-kanak dikatakan mempengaruhi kanak-kanak dari pelbagai aspek terutama dari cara kanak-kanak berfikir dan daya kognitif (Abas \& Hamzah, 2017; Meadows, 2017). Teknologi perisian dan perkakasan dalam dunia komputeran memberi ruang kepada kanak-kanak untuk akses dengan lebih mudah (Yanzhen \& Maizatul, 2019; Azniah, Maizatul, Noor \& Nor, 2016). Perisian dan peranti seperti tablet, iPad dan telefon pintar dikatakan menjadi permainan dan tren semasa dalam persekitaran pembelajaran kanak-kanak (Korucu \& Atıcı, 2018; Rosly \& Khalid, 2017; Therrien \& Light, 2016). Sejajar dengan perubahan dan perkembangan ini, kemahiran meta kognitif kanak-kanak dalam penggunaan perisian dan peranti terkini perlu dikaji.

\section{TINJAUAN LITERATUR}

\section{Pembelajaran Berasaskan Permainan}

Teori pemikiran sering dikaitkan dengan kajian yang melibatkan perkembangan kognitif kanak-kanak. Kajian sebegini memerlukan pemahaman dalam menerangkan gelagat individu hasil dari pengetahuan kognitif sedia ada. Kajian seumpamanya sering dikaitkan dengan empat peringkat tahap perkembangan kognitif yang diperkenalkan oleh Piaget (Bhagat, Haque, \& Jaalam, 2018). Piaget 
(1952) membuat kesimpulan dalam kajian terawalnya tentang cara berfikir kanak-kanak adalah berbeza berbanding orang dewasa dan ianya ada kaitan dengan bagaimana kanak-kanak menerima pengalaman dan berinteraksi dengan persekitarannya. Kajian beliau yang paling terkenal adalah mengenai perkembangan kognitif kanak-kanak.

Dalam kajian berkenaan, tahap perkembangan kognitif kanak-kanak telah dibahagikan kepada empat tahap mengikut usia kanak-kanak sejak mereka dilahirkan sehinggalah dewasa (Simons, Metzger, \& Sonnenschein, 2020; Louca, 2019; Papaleontiou-Louca \& Thoma, 2014). Jadual 1 menerangkan empat tahap perkembangan kognitif yang dihasilkan oleh Piaget dari aspek julat umur, proses kognitif dan huraian perkembangan yang berkaitan.

Jadual 1: Tahap Perkembangan Kognitif (Piaget, 1952)

\begin{tabular}{|c|c|c|c|}
\hline Tahap Perkembangan & Umur & Proses Kognitif & Huraian Perkembangan \\
\hline Deria Motor & $\begin{array}{l}\text { Lahir hingga } \\
2 \text { tahun }\end{array}$ & Skemata & $\begin{array}{l}\text { Pembangunan mental hasil dari pengetahuan } \\
\text { baharu yang melibatkan kemahiran motor seperti } \\
\text { melihat, mendengar, merasa, bermain dan } \\
\text { sebagainya. }\end{array}$ \\
\hline Pre-Operasi & $\begin{array}{c}2 \text { hingga } 7 \\
\text { tahun }\end{array}$ & Asimilasi & $\begin{array}{l}\text { Penerimaan maklumat baharu dan aplikasinya } \\
\text { untuk bertindakbalas dengan pengetahuan sedia } \\
\text { ada seperti berkomunikasi dan sebagainya. }\end{array}$ \\
\hline Operasi Konkrit & $\begin{array}{l}7 \text { hingga } 11 \\
\text { tahun }\end{array}$ & Akomodasi & $\begin{array}{l}\text { Pemikiran taakulan logik semakin stabil dan } \\
\text { bersedia melakukan penyesuaian bagi skemata } \\
\text { sedia ada. }\end{array}$ \\
\hline Operasi Formal & $\begin{array}{l}11 \text { tahun dan } \\
\text { ke atas }\end{array}$ & Keseimbangan & $\begin{array}{l}\text { Pemikiran abstrak yang lebih sistematik dan } \\
\text { seimbang antara pengetahuan, pengalaman dan } \\
\text { kepercayaan. }\end{array}$ \\
\hline
\end{tabular}

Sepanjang proses dalam keempat-empat tahap perkembangan ini, kanak-kanak dikatakan mempunyai fungsi deria yang berkembang pantas dan belajar sambil memerhati keadaan sekeliling melalui deria dan gerak balas. Kordinasi maklumat deria, kebolehan gerak balas dan kemahiran motor kanak-kanak akan membentuk pengalaman interaksi kanak-kanak dengan persekitaran mereka (Louca, 2019; Satlof-Bedrick \& Johnson, 2015).

Kajian terdahulu berkaitan dengan perkembangan kognitif atau meta kognitif kanak-kanak perlu diolah berdasarkan generasi atau populasi kanak-kanak (Shatto \& Erwin, 2017). Kajian tentang generasi kebiasaannya meletakkan segolongan manusia yang dibesarkan pada tempoh masa yang sama dalam situasi yang serupa sama ada dari segi ekonomi, politik, sosial kemasyarakatan mahupun teknologi (Schlebbe, 2020; Agarwal, 2014). Pembahagian generasi ini jika diteliti kebanyakannya merujuk kepada senario masyarakat yang membesar di negara Amerika Syarikat mahupun di Eropah dan dikaitkan dengan rentetan sejarah negara berkenaan. Corak pemikiran dan perkembangan pendidikan kanak-kanak di negara tersebut dikatakan berbeza dengan negara lain termasuklah dalam konteks di Malaysia (Zulkifli, Abidin, Mansor, Hamzah, \& Zulkifli, 2019; Anthony, 2019). 
Di Malaysia, generasi kanak-kanak membesar berkait rapat dengan situasi yang berlaku dalam kalangan masyarakat yang melibatkan perkembangan masyarakat Malaysia yang mempunyai ciri-ciri yang berbeza berbanding kajian Howe dan Strauss (2000). Misalnya era industri British, Perang Jepun, Merdeka, 13 Mei, Pasca Dasar Ekonomi Baru (DEB), Reformasi, Malaysia Baharu dan penularan virus Corona yang sedikit sebanyak telah membentuk norma baharu kehidupan. Rajah 1 mengambarkan pembahagian generasi mengikut tahun kelahiran dan ciri-ciri keperibadian mengikut generasi (Muhammad, Maizatul \& Suhairun, 2018).

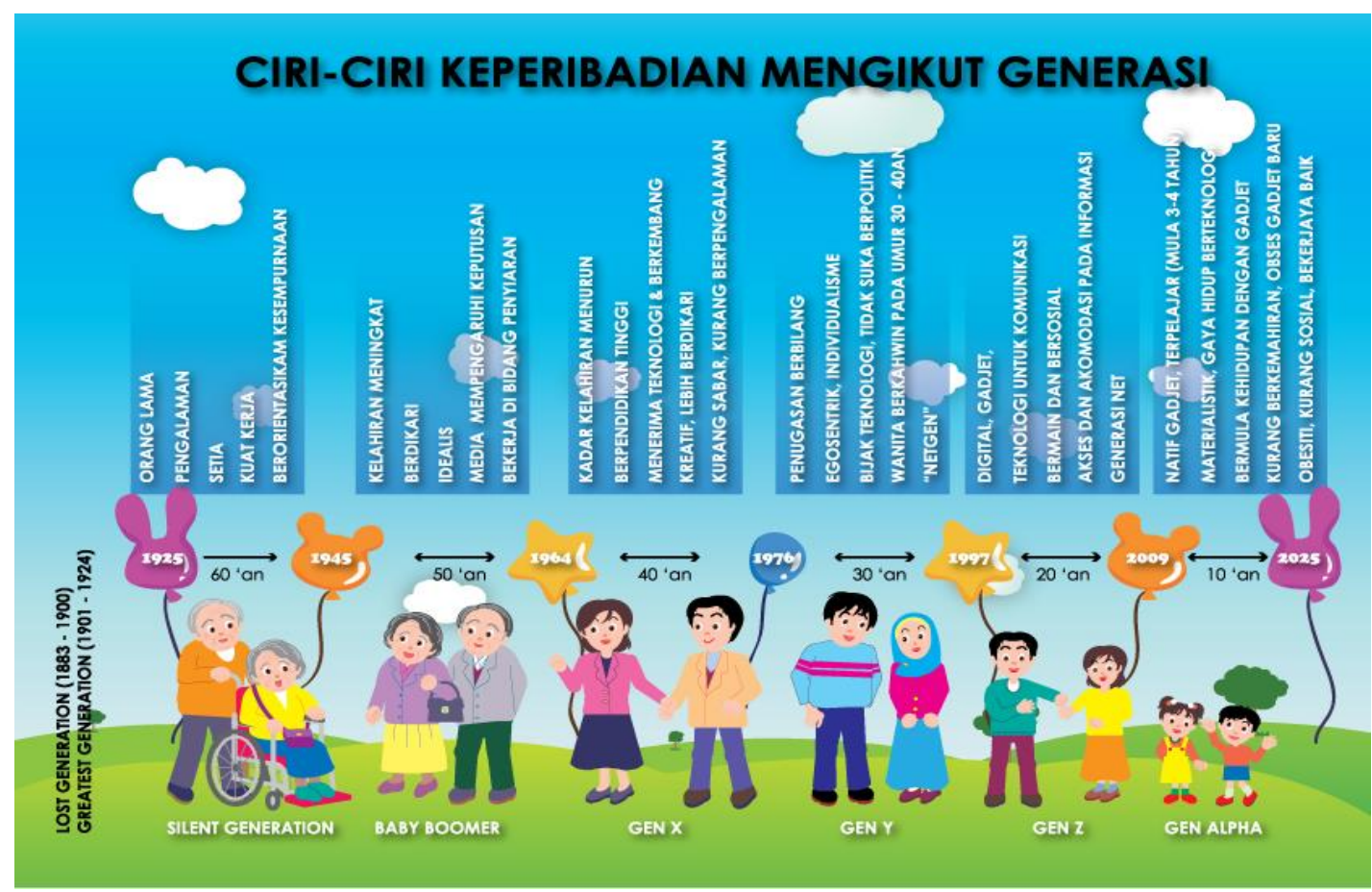

Rajah 1: Ciri-ciri keperibadian mengikut generasi

(Muhammad, Maizatul \& Suhairun, 2018)

Kanak-kanak dalam kelompok Generasi Z (Gen A) dan Generasi Alfa (Gen A) berbeza dengan generasi terdahulu dari pelbagai segi. Mereka lahir dalam zaman digital yang memudahkan mereka untuk akses kepada semua bentuk gajet (Chen, Park, \& Breazeal, 2020). Mereka juga dikatakan pengguna tegar bagi peralatan teknologi komputeran, aplikasi permainan dan aplikasi perisian yang terkini serta pelanggan utama perkhidmatan Internet (Laili \& Maizatul, 2014). Oleh kerana itu, mereka terlalu bergantung dan sangat memerlukan teknologi dalam kehidupan mereka. Cara mereka berkomunikasi nyata berbeza sehingga mampu membentuk satu rangkaian komunikasi secara global dan besar (massive). Namun begitu, golongan ini turut dikatakan mempunyai kelemahan yang ketara seperti agak lemah dari segi perwatakan diri, kemahiran interpersonal dan masalah komunikasi lisan 
(Buckley \& Doyle, 2017). Mereka boleh mengemukakan pendapat dan pandangan tetapi hanya melalui teknologi dan aplikasi Internet. Bagi generasi ini, kemahiran yang paling perlu dikuasai bagi generasi ini adalah kemahiran, pengetahuan dan kompetensi berkaitan dengan teknologi komputeran (Ozdal \& Ozdamli, 2017).

Teknologi komputeran melibatkan teknologi perkakasan, perisian, maklumat, tatacara dan manusia yang saling berhubung antara satu sama lain. Teknologi perkakasan secara piawai melibatkan perkakasan atau peranti seperti unit sistem, peranti input, peranti output, peranti storan dan peranti komunikasi (Comer, 2018). Kajian ini menumpukan kepada peranti input yang membolehkan data dan arahan dimasukkan oleh kanak-kanak ke dalam komputer menggunakan peranti input tanpa sentuhan. Kebiasaannya peranti input memerlukan pengguna untuk sentuh seperti papan kekunci, tetikus dan mikrofon.

Kajian ini pula menggunakan peranti input tanpa sentuhan yang memerlukan kanak-kanak menggerakkan jari dan tangan mereka untuk memasukkan data dan arahan ke dalam komputer. Pergerakan jari dan tangan merupakan salah satu antaramuka (interface) yang menggunakan teknologi pengecaman isyarat (gesture recognition) (Hong \& Kim, 2018). Ia dapat dilaksanakan dengan penggunaan kamera yang akan membaca gerakan berkenaan dan menyampaikan data ke dalam komputer. Teknologi ini banyak digunakan dalam kalangan pengguna yang cacat fizikal dan dikatakan mudah lentur dan bersifat azali (natural) berbanding dengan peranti input yang piawai (Faisal, Usman, Pirzada \& Hassan, 2016).

Kajian terdahulu yang berkaitan dengan penggunaan peranti tanpa sentuhan dalam kalangan kanakkanak turut membincangkan kelebihan dan cabaran yang dihadapi. Antara kelebihan penggunaan peranti tanpa sentuhan adalah pembelajaran dan pengalaman interaktiviti dalam kalangan kanakkanak, eksplorasi secara aktif (Chang, 2018), mempunyai keyakinan diri (Psycharis \& Kotzampasaki, 2019), persekitaran yang riang (Wang, Koh, Santacrose, Song, Klemfuss \& Dion, 2019) dan tahap penglibatan kanak-kanak yang tinggi (Chen, Feng, Liu, Wang \& Zhang, 2017). Namun cabaran besar yang perlu diatasi dalam melaksanakan penggunaan peranti tanpa sentuhan dalam kalangan kanakkanak adalah kegagalan dalam kompetensi kognitif dan kordinasi motor (Nur Syabila, Noris \& Rahmita, 2016; Naidu \& Ghotkar, 2016; Liang et al., 2015).

Tumpuan perbincangan dalam artikel ini berserta kajian terdahulu adalah berkaitan dengan konstruk meta kognitif yang berkait rapat dengan pemikiran. Perkataan meta membawa maksud tahap yang lebih tinggi. Ia turut merangkumi proses berfikir secara kreatif dan kritis, proses membuat keputusan dan proses menyelesaikan masalah (Gharial, 2017). Kesemua proses ini turut ditekankan dalam pemikiran komputasional seperti digariskan dalam Dokumen Standard Kurikulum Pentaksiran (DSKP) bermula dari Kurikulum Standard Prasekolah Kebangsaan (KSPK), Kurikulum Standard Sekolah Rendah (KSSR) dan Kurikulum Standard Sekolah Menengah (KSSM) (Kementerian Pendidikan Malaysia, 2013). 
Menurut Flavell (1979) dalam Febrina dan Mukhidin (2019), meta kognitif merupakan konstruk baharu yang memerihalkan "pemikiran dalam pemikiran" atau "belajar untuk belajar" yang menekankan proses pemantauan kognitif. Konstruk ini dibina hasil dari kelemahan Teori Pemprosesan Maklumat dalam menerangkan bagaimana proses pemikiran mengawal maklumat yang disimpan bagi tempoh jangka pendek dan jangka panjang (Mohamad \& Mahamod, 2013). Flavell telah memperkenalkan empat kelas fenomena dan hubungan antaranya yang berlaku dalam Model Pemantauan Kognitif yang melibatkan pengetahuan meta kognitif, pengalaman meta kognitif, matlamat dan strategi. Penjelasan berkaitan dengan perbezaan empat kelas fenomena ini diringkaskan dalam Jadual 2.

Jadual 2: Empat kelas fenomena dalam Model Pemantauan Kognitif Flavell (1979)

\begin{tabular}{ll}
\hline Kelas Fenomena & Pengertian \\
\hline Pengetahuan Meta Kognitif & Pengetahuan yang disimpan dalam ingatan manusia. \\
Pengalaman Meta Kognitif & Pengalaman yang diperolehi hasil dari pengetahuan. \\
Matlamat & Tugas yang perlu dilakukan. \\
Strategi & Tindakan yang akan dilakukan. \\
\hline
\end{tabular}

Bagi memahami cabaran perubahan teknologi yang pesat ini, tumpuan terhadap kemahiran meta kognitif kanak-kanak dalam generasi semasa sememangnya penting kerana masa depan negara bergantung kepada kualiti dalam pembentukan pemikiran kanak-kanak (Bakar \& Ismail, 2019). Kemahiran meta kognitif dalam kalangan kanak-kanak generasi semasa dikatakan akan membantu mereka untuk mengurus, mengawal dan bertanggung jawab ke atas proses pembelajaran mereka sendiri (Nachiappan, Julia, Abdullah, Sehgar, Suffian \& Sukri, 2019). Ciri-ciri ini penting dalam membantu perkembangan pengetahuan kanak-kanak. Justeru itu, kajian berkaitan dengan kemahiran meta kognitif kanak-kanak dalam penggunaan perisian dan peranti terkini dilaksanakan dan dilaporkan dalam artikel ini.

Artikel ini membincangkan dapatan kajian berkaitan peranti tanpa sentuhan dan kemahiran meta kognitif kanak-kanak berdasarkan empat kelas fenomena dalam Model Pemantauan Kognitif Flavell (1979) bagi tiga persoalan berikut:

1. Bagaimana penggunaan peranti input tanpa sentuhan bagi kanak-kanak berusia empat tahun dalam meningkatkan kemahiran meta kognitif?

2. Bagaimana kesesuaian jenis interaksi dan antara muka perisian aplikasi pembelajaran kanakkanak mampu memberi kesan terhadap peningkatan kemahiran meta kognitif?

3. Bagaimana kanak-kanak dapat menggunakan peranti input tanpa sentuhan melalui isyarat gerakan?

\section{METODOLOGI}

Kajian ini menggunakan pendekatan kualitatif menggunakan kaedah kajian kes deskriptif. Kaedah ini dipilih bagi mendapatkan hasil kajian yang menjawab persoalan mengapa dan bagaimana dengan lebih terperinci dan menyeluruh (Yahaya, Voo, Maakip, \& Malek, 2017). Kajian kes deskriptif dilakukan secara terperinci dan intensif ke atas satu unit sosial yang kecil. Dalam aspek ini, reka bentuk kajian 
dibatasi oleh aktiviti seperti yang dibayangkan iaitu interaksi kanak-kanak menggunakan peranti tanpa sentuhan dan kaitannya dengan kemahiran meta kognitif mereka. Pemilihan responden ditentukan oleh guru menggunakan persampelan bertujuan dan melibatkan hanya seorang peserta kajian. Peserta kajian adalah seorang kanak-kanak perempuan berusia empat tahun dari sebuah taska di Daerah Mualim, Perak Darul Ridzuan.

Dalam kajian kes ini, data naratif dikutip hasil dari temu bual dengan tiga orang guru yang mengajar kanak-kanak berkenaan, rekod dari rakaman video dan kesimpulan daripada pemerhatian secara berstruktur tentang interaksi kanak-kanak dengan peranti input tanpa sentuhan berkenaan. Peranti tanpa sentuhan yang dipilih adalah Leap Motion Controller (Ultra Leap Limited; 2020) dan tiga perisian aplikasi pembelajaran yang dipilih adalah Caterpillar Count, Playground dan Robot Dance yang boleh dimuat turn dari sesawang Leap Motion App Home (Leap Motion Gallery, 2020).

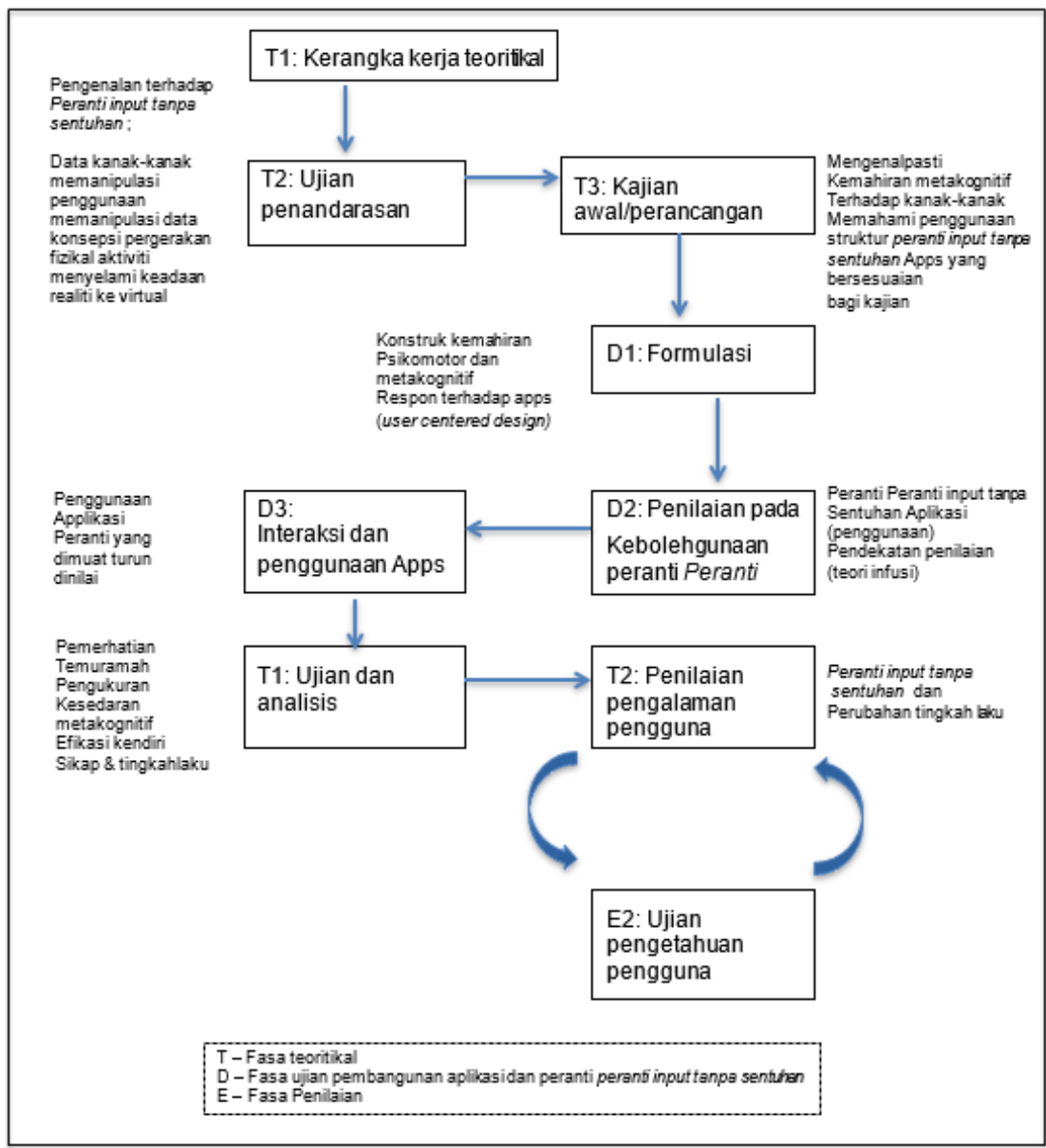

Rajah 2: Carta alir proses pelaksanaan kajian 
Rajah 2 menunjukkan carta alir proses kajian yang dijalankan yang menggambarkan bagaimana kaedah temu ramah, rakaman video dan sesi pemerhatian berstruktur dilaksanakan. Prosedur kajian membabitkan teknik ikut serta yang mana penyelidik melakukan pemerhatian secara langsung dalam suasana pembelajaran semulajadi menggunakan tiga perisian aplikasi bagi tiga sesi aktiviti pembelajaran. Gelagat dan perbualan kanak-kanak dicatat mengikut masa dan prosedur ini memperolehi persetujuan dari pihak pengurusan terlebih dahulu sebelum dimulakan.

\section{HASIL DAPATAN DAN PERBINCANGAN}

\section{Soalan Kajian Pertama \\ Penggunaan Peranti Input Tanpa Sentuhan Bagi Kanak-Kanak Berusia Empat Tahun dalam Meningkatkan Kemahiran Meta Kognitif}

Data naratif hasil dari rakaman video dan temu bual bersama guru mendapati kanak-kanak berusia empat tahun ini menunjukkan penerimaan yang sangat baik semasa menggunakan peranti Leap Motion Controller. Dari rakaman video dan hasil pemerhatian mendapati kanak-kanak tersebut mempamerkan kelebihan dalam penguasaan peranti berkenaan melalui proses eksplorasi pada ketiga-tiga sesi aktiviti pembelajaran yang dilakukan.

Dari aspek kelas fenomena pengetahuan meta kognitif, kanak-kanak ini berjaya memperlihatkan literasi dan pengetahuan meta kognitif mereka dalam penggunaan peranti komputer dan berjaya menggunakan ketiga-tiga perisian aplikasi yang terlibat. Kelas fenomena pengalaman meta kognitif pula menunjukkan bahawa kanak-kanak ini berkemampuan dalam menyusun dan mengkordinasi maklumat yang diperlukan dalam aktiviti pembelajaran berkenaan. Kelas fenomena matlamat serta kelas fenomena strategi juga berjaya dicapai. Kecenderungan kanak-kanak berusia empat tahun ini untuk memahami matlamat akktiviti dan berjaya mengikuti ketiga-tiga aktiviti pembelajaran dengan baik. Setiap kawalan motor halus semasa menggunakan Leap Motion Controller adalah bersela. Ini menunjukkan kanak-kanak ini mempunyai strategi yang membolehkannya berinteraksi dengan peranti input tanpa sentuhan dengan baik.

Jadual 3 menunjukkan transkrip hasil temu bual bersama guru terhadap hubungan antara penggunaan peranti input tanpa sentuhan bagi kanak-kanak berusia empat tahun dalam meningkatkan kemahiran meta kognitif: 
Jadual 3: Transkrip temubual bagi persoalan pertama

\begin{tabular}{|c|c|}
\hline Kod Responden & Transkrip \\
\hline P1-TB4-KK34-RO1RQ1-8 & $\begin{array}{l}\text { "...ya, kanak-kanak ini memperlihatkan kecenderungan pembelajaran } \\
\text { mereka berbantukan peralatan berteknologi..." }\end{array}$ \\
\hline P1-TB4-KK34-RO1RQ1-21 & $\begin{array}{l}\text { “...hubungan kanak-kanak ini dan teknologi ini mewujudkan satu } \\
\text { hubungan penjelmaan yang mana kanak-kanak ini menghubungkan } \\
\text { dirinya dan teknologi menjadi satu kemestian dalam mencapai sesuatu } \\
\text { matlamat dengan pemantauan dan penilaian yang setara dengan } \\
\text { kemampuannya..." }\end{array}$ \\
\hline P1-TB4-KK34-RO1RQ1-23 & $\begin{array}{l}\text { “...kanak-kanak ini sedar akan persekitaran pembelajaran dia dengan } \\
\text { cara menerokai dan menyelusuri maklumat dan pengetahuan tanpa } \\
\text { batasan...” }\end{array}$ \\
\hline
\end{tabular}

\section{Soalan Kajian Kedua}

\section{Kesesuaian Jenis Interaksi dan Antara Muka Perisian Aplikasi Pembelajaran Kanak-Kanak Mampu Memberi Kesan Terhadap Peningkatan Kemahiran Meta Kognitif}

Interaksi dan gelagat kanak-kanak berusia empat tahun ini dirakam menggunakan perakam video dan seterusnya video berkenaan dikaji dari aspek jenis interaksi dan jenis antara muka perisian aplikasi pembelajaran yang digunakan. Data naratif mendapati kanak-kanak ini memperlihatkan potensi peranti input tanpa sentuhan ini sebagai alat pembelajaran yang berkesan. Kanak-kanak ini mula bertanyakan sesuatu (misalnya bagaimana, apakah dan mengapa) sebelum permulaan pembelajaran menggunakan Leap Motion Controller. Kelihatan kanak-kanak ini memulakan aktiviti pembelajaran dengan membentuk skema pemikiran yang kukuh, mengolah data dan maklumat yang diperolehi dari persekitaran pembelajaran mereka. Secara tidak langsung, proses mendapatkan maklumat ini akan disimpan dalam memori jangka penjang berbanding jangka pendek kerana proses ini dapat menentukan tindakbalas manusia dengan persekitaran. Dapatan ini disokong oleh hasil temu bual yang digambarkan dalam Jadual 4:

Jadual 4: Transkrip temubual bagi persoalan kedua (umum)

\begin{tabular}{|c|c|}
\hline Kod Responden & Transkrip \\
\hline P1-TB4-KK34-RO1RQ2-6 & $\begin{array}{l}\text { "...televisyen, komputer, tab dan konsol Xbox untuk pengajaran dan } \\
\text { eksplorasi kanak-kanak terhadap pembelajaran dia...." }\end{array}$ \\
\hline P1-TB4-KK34-RO1RQ2-8 & $\begin{array}{l}\text { “...kanak-kanak ini mampu menggunakan peranti input tanpa sentuhan } \\
\text { tadi dengan baik...” }\end{array}$ \\
\hline P1-TB4-KK34-RO1RQ3-8 & $\begin{array}{l}\text { “...saya diperlihatkan dengan satu kebolehan kanak-kanak ini } \\
\text { menggunakan pengalamannya sebelum ini dengan gajet-gajet yang } \\
\text { pernah dia gunakan...” }\end{array}$ \\
\hline
\end{tabular}

Tahap interaksi kanak-kanak berusia empat tahun terhadap penggunaan peranti input tanpa sentuhan adalah sangat baik. Melalui interaktiviti secara terus di antara kanak-kanak berusia empat tahun dengan peranti input tanpa sentuhan, kanak-kanak ini dikatakan mempunyai motivasi yang baik dan mudah 
menyelesaikan tugasan dalam sesi aktiviti pembelajaran yang diberikan. Dapatan ini disokong oleh hasil temu bual yang digambarkan dalam Jadual 5:

Jadual 5: Transkrip temubual bagi persoalan kedua (jenis interaksi)

\begin{tabular}{|c|c|}
\hline Kod Responden & Transkrip \\
\hline P1-TB4-KK34-RO2RQ4-19 & $\begin{array}{l}\text { "...dengan kawalan motor halus mereka iaitu tangan mereka dan seumpama } \\
\text { mereka di dalam paparan, ya, walaupun hanya tangan mereka tapi mereka } \\
\text { merasakan diri mereka "connect" dengan aktiviti yang disediakan..." }\end{array}$ \\
\hline P1-TB4-KK34-RO2RQ4-23 & $\begin{array}{l}\text { “...interaksi ini membolehkan mereka berfikir dengan cara kritis dan kreatif } \\
\text { dalam menyelesaikan masalah..." }\end{array}$ \\
\hline P1-TB4-KK34-RO2RQ4-25 & $\begin{array}{l}\text { "... saya lihat ianya lebih interaktif dengan interaktiviti pelbagai hala, sama } \\
\text { ada dengan peranti, diri mereka sendiri mahupun, rakan mereka..." }\end{array}$ \\
\hline
\end{tabular}

Kanak-kanak berusia empat tahun ini pantas mengadaptasi pengalaman serta pengetahuan yang sedia ada untuk digandingkan dengan kemahiran motor halusnya. Misalnya dalam sesi aktiviti pembelajaran menggunakan perisian aplikasi Robot Dance, kanak-kanak ini faham keperluan tugasan untuk menyambung bongkah-bongkah untuk membentuk kepala dan badan robot. Ini dapat dilihat dengan antaramuka perisian aplikasi yang mudah, musik latar yang menarik serta kesan bunyi yang banyak membantu kanak-kanak ini menumpukan kepada kordinasi pergerakan motor halus melalui meta tumpuan dan meta pemahaman mereka. Ini menunjukkan kemahiran meta kognitif kanak-kanak ini meningkat dan luahan dari kanak-kanak ini menunjukkan emosi kepuasannya dalam menyelesaikan tugasan yang diberikan. Dapatan ini turut disokong oleh guru yang ditemubual yang menyatakan pernyataan dalam Jadual 6:

Jadual 6: Transkrip temubual bagi persoalan kedua (jenis antaramuka)

\begin{tabular}{ll}
\hline Kod Responden & Transkrip \\
\hline P1-TB4-KK34-RO2RQ5-27 & $\begin{array}{l}\text { “...kanak-kanak ini mudah untuk mengkaitkan antara pembelajaran dan } \\
\text { persekitarannya. Paparan yang jelas dengan bentuk-bentuk yang mudah } \\
\text { difahami, tersusun. Membantu kanak-kanak menyusun skema mereka } \\
\text { dengan lebih mudah...” }\end{array}$ \\
& $\begin{array}{l}\text { “...keperluan kanak-kanak, mereka lebih suka kepada yang mudah dan } \\
\text { jelas dari sudut maksud dengan apa yang disampaikan. Rupa, bentuk serta } \\
\text { Penggunaan warna yang terang lebih perlu ditekankan agar fokus mereka } \\
\text { lebih terangsang untuk melakukan aktiviti...” }\end{array}$ \\
\hline
\end{tabular}

\section{Soalan Kajian Ketiga}

Penggunaan Peranti Input Tanpa Sentuhan Menggunakan Isyarat Gerakan Bagi Kanak-Kanak

Kanak-kanak empat tahun yang terlibat dalam kajian ini berjaya menghubungkan pengalaman lepas dan menterjemahkan keperluan tugasan dalam setiap sesi aktiviti pembelajaran. Dalam temu bual bersama guru, kanak-kanak ini menampilkan kelangsungan dalam pembentukan keyakinan diri yang baik hasil dari pengalaman lepas. Kelihatan kanak-kanak ini dapat menghubungkan pengalaman 
baharu menggunakan sumber pengetahuan baharu, menunjukkan reaksi menilai dan memantau semasa di akhir sesi aktiviti pembelajaran, seperti yang dinyatakan antaranya dalam Jadual 7:

Jadual 7: Transkrip temubual bagi persoalan ketiga

\begin{tabular}{|c|c|}
\hline Kod Responden & Transkrip \\
\hline P1-TB4-KK34-RO3RQ6-31pts(i) & $\begin{array}{l}\text { “...kanak-kanak ini lebih baik dalam mengawal serta menterjemahkan } \\
\text { keperluan setiap tugasan...” }\end{array}$ \\
\hline P1-TB4-KK34-RO3RQ6-31pts(ii) & $\begin{array}{l}\text { "...kawalan motor halus serta koordinasi tangan dan otaknya saling } \\
\text { berhubung dan menghasilkan satu output yang sangat positif..." }\end{array}$ \\
\hline P1-TB4-KK34-RO3RQ6-31pts(iii) & $\begin{array}{l}\text { “...saya perhatikan kanak-kanak ini agak aktif dalam kelas, tetapi dalam } \\
\text { sesi kajian ini, dia menunjukkan perkembangan yang positif dengan cara } \\
\text { dia fokus pada setiap tugasan yang diberikan, sahsiahnya terjaga dan sedia } \\
\text { membantu rakannya yang kurang mahir dengan tugasan yang } \\
\text { diberikan..." }\end{array}$ \\
\hline
\end{tabular}

\section{KESIMPULAN}

Kajian penggunaan peranti input tanpa sentuhan dalam kalangan kanak-kanak ini, bukan hanya menumpukan kepada kemahiran meta kognitif kanak-kanak meningkat, bahkan kemahiran motor halus juga terbina melalui pengawalan pergerakan jari dan tangan mereka. Kemahiran meta kognitif yang melalui empat kelas fenomena dalam Model Pemantauan Kognitif Flavell telah dikupas menggunakan kajian kes seorang kanak-kanak berusia empat tahun. Walaupun pada tahap umur ini agak muda, kanak-kanak berkenaan dapat memperlihatkan penilaian positif dalam penggunaan peranti input tanpa sentuhan terhadap kemahiran meta kognitif kanak-kanak. Ini memberi implikasi terhadap peralihan teknologi dan kesannya kepada kanak-kanak dari Generasi Alfa. Guru yang mendidik kanakkanak dari Generasi Alfa boleh memikirkan kesesuaian teknologi komputeran yang boleh digunakan dalam pengajaran dan pembelajaran selari dengan keperluan pendidikan abad ke-21.

\section{PENGHARGAAN}

Ucapan terima kasih kepada kanak-kanak dan guru dari Pusat Data Kanak-Kanak Kebangsaan (NCDRC), Universiti Pendidikan Sultan Idris (UPSI) atas kerjasama yang diberikan sepanjang kajian ini berlangsung.

\section{RUJUKAN}

Abas, W.A.W., \& Hamzah, A. (2017). Media dalam kehidupan dan perkembangan kanak-kanak. Malaysian Journal of Media Studies, 15(2), 27-39.

Agarwal, N.K. (2014). Use of touch devices by toddlers or preschoolers: observations and findings from a single-case study. New Directions in Children's and Adolescents' Information Behavior Research, 3-37.

Anthony, L. (2019). Physical dimensions of children's touchscreen interactions: Lessons from five years of study on the MTAGIC project. International Journal of Human-Computer Studies. 128, 1-16.

Azniah, I., Maizatul Hayati, M.Y., Noor Azida, S., \& Nor Zuhaidah, M.Z. (2016). Keupayaan murid sekolah rendah mempelajarii dan menerokai bahasa pengaturcaraan visual. Journal of Information and Communication Technology in Education (JICTIE), 3(1), 89-97. 
Bakar, M.A.A. \& Ismail, N. (2019). Impak pelaksanaan strategi pembelajaran regulasi metakognitif dalam pembelajaran matematik: Satu kajian literatur. Jurnal Dunia Pendidikan, 1(1), 18-26.

Bhagat, V., Haque, M., Jaalam, K., (2018). Enrich schematization in children: Play as the tool for cognitive development. Journal of Applied Pharmaceutical Science, 8(7), 128-131.

Buckley, P. \& Doyle, E. (2017). Individualising gamification: An investigation of the impact of learning styles and personality traits on the efficacy of gamification using a prediction market. Computers \& Education, 106, 43-55.

Chang, A. (2018). Exploratory programming in the classroom. In proceedings of the 2018 Connected Learning Submit. 27-35.

Chen, H., Park, H.W., \& Breazeal, C. (2020). Teaching and learning with children: Impact of reciprocal peer learning with a social robot on children's learning and emotive engagement. Computers \& Education, 150, 103836.

Chen, Z., Feng, X., Liu, T., Wang, C., \& Zhang, C. (2017). A computer-assisted teaching system with gesture recognition technology and its applications. In proceedings of the International Conference on Digital Technology in Education, 1-6.

Comer, D.E. (2018). The Internet book: Everything you need to know about computer networking and how the Internet works. New York: CRC Press.

Faisal, N., Usman, M., Pirzada, P., \& Hassan, A. (2016). Innovating e-learning concepts in special education by gesture recognition using kinect. Asian Journal of Engineering, Sciences \& Technology, Special Issue, 44-49.

Febrina, E. \& Mukhidin, M. (2019). Metakognitif sebagai keterampilan berfikir tingkat tinggi pada pembelajaran abad 21. Edusentris, 6(1), 25-32.

Flavell, J.H. (1979). Metacognition and cognitive monitoring: A new area of cognitive-developmental inquiry. American Psychologist, 34(10), 906.

Gharial, G.K. (2017). Correlation analysis of metacognition and multiple intelligence of rural adolescents. Doctoral Dissertation, Punjab Agricultural University, Ludhiana.

Hong, S. \& Kim, E. (2018). Development of gesture recognition education game for elementary school students personality education. In proceedings of the International Conference on Human-Computer Interaction. Springer, Cham. 25-30.

Howe, N. \& Strauss, W. (2000). Millennials rising: The next great generation. Vintage.

Kementerian Pendidikan Malaysia (2013). Pelan pembangunan pendidikan Malaysia 2013-2025. Putrajaya: Kementerian Pendidikan Malaysia.

Korucu, A. \& Atıc1, K. (2018). The determination of metacognitive awareness situations of secondary school students receiving programming education with Alice. Journal of Learning and Teaching in Digital Age, 3(1), 3-11.

Laili Farhana, M.I. \& Maizatul Hayati, M.H. (2014). Kreativiti dan kemahiran kanak-kanak dalam mereka bentuk permainan digital bagi tujuan pembelajaran. Journal of Information and Communication Technology in Education (JICTIE), 1(1), 87-102.

Leap Motion Gallery (2020). Leap Motion App Store. Retrieved date 6 May 2020, from Leap Motion App Store, https://gallery.leapmotion.com/category/app-store/

Liang, H., Chang, J., Kazmi, I.K., Zhang, J.J., \& Jiao, P. (2015). Puppet narrator: Utilizing motion sensing technology in storytelling for young children. In proceedings of the 7th Int. Conf. Games Virtual Worlds Serious Application. 1-8.

Louca, E.P. (2019). Do children know what they know? Metacognitive awareness in preschool children. New Ideas in Psychology, 54, 56-62.

McCrindle, M. (2018). What comes after Generation Z? Introducing Generation Alpha [web log comment].

Meadows, S. (2017). Developing thinking: Approaches to children's cognitive development. Boston: Routledge.

Mohamad, N.A. \& Mahamod, Z. (2013). Kemahiran meta kognitif dan hubungannya dengan jantina, jenis sekolah dan pencapaian murid dalam pembelajaran Bahasa Melayu. Jurnal Pendidikan Malaysia, 38(2), 23-32.

Muhammad Modi, L., Maizatul Hayati, M.Y. \& Suhairun, N.S. (2018). Pengenalan pembelajaran teradun. In M.Y. Maizatul Hayati \& A. Ummu Husna. Pembelajaran Teradun: Trend, Isu dan Amalan (pp. 3-14). Tanjong Malim: Pejabat Karang Mengarang Universiti Pendidikan Sultan Idris.

Nachiappan, S., Julia, I.P., Abdullah, N., Sehgar, S.C., Suffian, S., \& Sukri, N.A. (2019). Pelaksanaan kemahiran berfikir aras tinggi oleh guru dalam pengajaran dan pembelajaran di tadika. Jurnal Pendidikan Awal Kanak-Kanak Kebangsaan, 8, 24 32.

Nahar, N., Sangi, S., Rosli, N., \& Abdullah, A.H. (2018). Impak negatif teknologi moden dalam kehidupan dan perkembangan kanak-kanak hingga usia remaja. UMRAN-International Journal of Islamic and Civilizational Studies, 5(1).

Naidu, C. \& Ghotkar, A. (2016). Hand gesture recognition using leap motion controller. International Journal of Science Research, 5(10), 436-441.

Nur Syabila, Z., Noris, M.N., \& Rahmita, W. (2016). A Review on gesture recognition technology in children's interactive storybook. In proceedings of the 4th International Conference on User Science and Engineering (i-USEr 2016). DOI: 10.1109/IUSER.2016.7857966

Nurul Syadiyah, K. \& Ramlah, M. (2020). Pembelajaran berasaskan permaian dalam mata pelajaran sejarah menggunakan teknik mnemonik. Journal of Information and Communication Technology in Education (JICTIE), 7(1), 9-15.

Ozdal, H. \& Ozdamli, F. (2017). The effect of infographics in mobile learning: case study in primary school. Journal of Universal Computer Science, 23(12), 1256-1275.

Papaleontiou-Louca, E. \& Thoma, N. (2014). A review of young children's metacognitive ability of 
introspection. Contemporary Perspectives on Research in Theory of Mind in Early Childhood Education, 225.

Piaget, J. (1952). The origins of intelligence in children. New York, USA: International Universities Press. Available at http://www.pitt. edu/ strauss/origins_r.pdf [6 May, 2020].

Psycharis, S. \& Kotzampasaki, E. (2019). The impact of a STEM inquiry game learning scenario on computational thinking and computer self-confidence. EURASIA Journal of Mathematics, Science and Technology Education, 15(4), 1-18.

Rosly, M.R. \& Khalid, F. (2017). Gamifikasi: Konsep dan implikasi dalam pendidikan. Pembelajaran Abad ke-21: Trend Integrasi Teknologi, 144-154.

Rusman, N.S., Ismail, H.N., \& Jaafar, S.M.R.S. (2019). Demand of preschool education by alpha generation on edutainment leisure in the city. International Journal of Built Environment and Sustainability, 6(1-2), 121-128.

Satlof-Bedrick, E. \& Johnson, C.N. (2015). Children's metacognition and mindful awareness of breathing and thinking. Cognitive Development, 36, 83-92.

Schlebbe, K. (2020). Watching, playing, making, learning: Young children's use of mobile devices. In proceedings of the International Conference on Information. Springer, Cham, 288-296.

Shatto, B. \& Erwin, K. (2017). Teaching millennials and generation Z: Bridging the generational divide. Creative Nursing, 23(1), 24-28.

Simons, C., Metzger, S.R., \& Sonnenschein, S. (2020). Children's metacognitive knowledge of five key learning processes. Translational Issues in Psychological Science, 6(1), 32.

Therrien, M. C. \& Light, J. (2016). Using the iPad to facilitate interaction between preschool children who use AAC and their peers. Augmentative and Alternative Communication, 32(3), 163-174.

Ultra Leap Limited (2020). Leap Motion Controller. Retrieved date 6 May 2020, from Ultra Leap Website, https://www.ultraleap.com

Wang, Q., Koh, J.B.K., Santacrose, D., Song, Q., Klemfuss, J.Z., \& Doan, S.N. (2019). Child-centered memory conversations facilitate children's episodic thinking. Cognitive Development, 51, 58-66.

Yahaya, A., Voo, P., Maakip, I, \& Malek, M.D.A. (2017). Kaedah penyelidikan dalam pendidikan. Tanjong Malim: Pejabat Karang Mengarang UPSI.

Yanzhen, W. \& Maizatul Hayati, M.Y. (2019). A framework of childhood obesity prevention through game-based learning. In: T.W. Hoe (Ed.). Design, motivation, and frameworks in game-based learning. ISI Global, 154-183. DOI: 10.4018/978-15225-6026-5

Zulkifli, F., Abidin, R.Z., Mansor, Z., Hamzah, M.H.M., \& Zulkipli, F. (2019). Use of learning aids on advancing students' thinking ability. Jurnal Inovasi Malaysia, 1(2), 1-22. 